\title{
Production and statistical optimization of biodiesel from kitchen chimney dump lard
}

\author{
Mayur Mausoom Phukan ${ }^{\text {* }}$, Salam Pradeep Singh ${ }^{1}$, Pinkee Phukon ${ }^{1}$, Tapanjit Borah², Bolin Kumar Konwar ${ }^{1}$ \\ and Nipu Dutta ${ }^{3}$
}

\begin{abstract}
Background: The global upsurge in world energy demand, sharp decline in petrofuels reserves, and greater concerns about the environment has constrained mankind to investigate newer and renewable feedstocks for liquid transportation fuels. Existent bioenergy feedstocks cannot suffice for the petro crude reserves, new feedstock for the same will serve as an incremental step for addressing the long recognized problem of energy supply and simultaneously also support further research endeavors related to green chemistry, feed stock biology and bioenergy research. In this regard, the present investigation aims to highlight kitchen chimney dump lard (a bio-waste), as a prospective feedstock for biodiesel production.
\end{abstract}

Results: Statistical implication (response surface methodology, RSM) can be helpful in design of experiments for biodiesel production and allied approaches. Biodiesel was produced from KCDL which contains high amount of free fatty acids (acid value $28 \mathrm{mg} \mathrm{KOH} / \mathrm{gm}$ ) by a two stage transesterification process. The biodiesel yield was optimized using RSM for optimal production and the yield was found to be $82 \%$ compared to $80 \%$ predicted using RSM. The biodiesel was characterized by CHN, GC-MS and FTIR spectroscopy. The fuel properties namely density, viscosity, cloud point, pour point, flash point and calorific value were analyzed to access the quality of the fuel. The results suggest the feasibility of biodiesel production from KCDL.

Conclusion: Production of biodiesel from KCDL is feasible and warrants necessary research.

Keywords: Energy, Feedstock, Kitchen chimney dump lard, RSM, Transesterification, FTIR

\section{Background}

Human society is witnessing transition from a petroleum based liquid fuel infrastructure to one based on renewable sources [1]. The continuous depletion of fossil energy sources and concerns over carbon dioxide emissions has further shifted the global trend towards development of new and consistent bio-based resources [2]. The exhaustion of petroleum based fuels is foreseeable and resultant scientific endeavors are on the cards for investigating new renewable energy sources for biofuel production. One of the high priority options for addressing this expedition for the search of new energy sources can be offered by energy derived from biomass. Biomass has the potential to become one of the major global pri-

\footnotetext{
* Correspondence: mayur_101@yahoo.com

'Department of Molecular Biology \& Biotechnology, School of Science \&

Technology, Tezpur University, Assam Napaam-784028, India

Full list of author information is available at the end of the article
}

bio-energy systems are suggested to be significant contributors to futuristic sustainable energy systems and to sustainable development in industrialized as well as in developing nations [3-12].

Scientific exploration and utilization of new bio-energy feedstocks for biofuel production is a fundamental task in fostering bio-energy research and sustainable development. Much emphasis has been laid on identification of suitable biomass feedstocks which can provide high energy output to replace conventional fossil fuel energy sources [13]. The greatest share of biofuel production cost is associated with feedstock, therefore the availability of low cost and good quality feedstock is crucial for large scale commercial use of biofuels [14-16]. The high prices of commodity vegetable oils and animal fats have made exploration of economical alternative non-food feedstocks an important research topic [17]. The production of biofuels especially biodiesel from low cost and inexpensive feedstocks like non-edible oils, animal
(C) Chemistry Central

(c) 2013 Phukan et al.; licensee Chemistry Central Ltd. This is an Open Access article distributed under the terms of the Creative Commons Attribution License (http://creativecommons.org/licenses/by/2.0), which permits unrestricted use, distribution, and reproduction in any medium, provided the original work is properly cited. 
fats, waste frying oils, agro-wastes etc have already gathered the scientific momentum in lieu of concerns for reduction in cost of production and economic compatibility with petro-diesel.

As extensive search operations for new feedstocks continues, even wastes (agro-wastes, municipal wastes, industrial wastes, waste cooking oil etc.) have started hitting the block. Under the aegis of green chemistry, bioenergy research and feedstock biology, energy generation from waste seems to be partially compassionate in addressing issues related to renewable liquid fuels. Moreover with the advancement in biomass conversion technologies the day is not far when a fraction of the international road fuel needs, could potentially be addressed by biofuel production from wastes. For a third world economy like India, biofuel production from waste is attractive not only with regard to energy security, but also in terms of environmental context (waste disposal and management) and economic aspect (revenue generation from subsequent energy recovery). Judicious and optimal use of total energy generation potential from inexpensive feedstocks/bio-wastes could unlock new vistas for abating the long term dilemma of energy supply. In this regard, the present investigation aims to highlight a bio-waste generated from kitchen chimneys, kitchen chimney dumped lard (KCDL), as a prospective feedstock for biodiesel production. Some of the salient features of KCDL towards bioenergy generation are

1) It is primarily a kitchen waste, and can be of great value with respect to energy recovery.

2) It can be easily accessed from kitchen chimneys of hotels, restaurants, hostels and large cooking facilities".

3) It is renewable as the primary feedstock is a vegetable oil.

4) KCDL based biodiesel has a good energy content $(36.5 \mathrm{MJ} / \mathrm{Kg})$

5) It has low ash content (0.05\%).

6) KCDL based biodiesel has good degree of saturation (41.86\%) thereby making it more stable.

Increased reliance on wastes (such as KCDL) for energy generation may play an incremental role in slowly reducing mankind's dependence on fossil fuels in coming days. The availability of the KCDL used in the present investigation depend upon numerous factors such as frequency of cooking, types of oils used for cooking, types of food items being cooked (especially deep fried food stuffs) etc. It is formed as a result of frying processes where the vapors of the cooking oil after condensation gets collected in semi solid form in the collecting ducts of a kitchen chimney.
The current work is an endeavor to investigate KCDL as a prospective new and renewable feedstock for biodiesel production and subsequent statistical optimization of biodiesel yield using response surface methodology. The feasibility of transesterification process via two stage transesterification and determination of fuel properties viz. density, viscosity, cloud point, pour point, flash point, and calorific value were further done to access the quality of KCDL based biodiesel.

\section{Results and discussion}

The identification of suitable feedstock and subsequent biomass conversion would contribute significantly towards futuristic bio-energy utilities. The graphical representation for the scheme of work done (from feedstock collection to biodiesel production and fuel characterization) has been shown in Figure 1. The feedstock used for this study, KCDL was collected from the kitchen chimney of Nilachal Men's Hostel, Tezpur University, Assam-784028, India $\left(26.7008^{\circ} \mathrm{N}\right.$ and $\left.92.8303^{\circ} \mathrm{E}\right)$. KCDL is primarily a kitchen waste (a bio-waste which is renewable in nature, since the primary feedstock is a vegetable oil) which can be collected from the horizontal collecting ducts present in a kitchen chimney. It is formed as a result of frying processes where the vapors of the cooking oil after condensation gets collected in semi solid form in the collecting ducts of a kitchen chimney. KCDL feedstock (light brown in color and murky odor) had a density of $2.01 \mathrm{gm} / \mathrm{cc}$, average molecular weight of 825.02 and an acid value of $28 \mathrm{mg} \mathrm{KOH} / \mathrm{gm}$, but however there may be variability in physical properties of the feedstock which is chiefly governed by product purity and time of exposure of the feedstock to atmospheric oxygen.

Numerous research work have been carried out on biodiesel production from waste oils or animal fats, describing the practicability of making quality biodiesel from these feedstocks thereby identifying the problems with the free fatty acids (FFA) present in these raw materials. The presence of FFA and water in these feedstocks results in soap production in the presence of alkali catalyst. Henceforth, additional steps for water removal and either the FFA or soap from the reaction mixture are required [18]. Special processes are required for transesterification of fat/oils containing significant amount of free fatty acids. Pretreatment processes using strong acid catalyst have been shown to provide good conversion yields and high quality final products [19]. One of the common methods employed to reduce the free fatty acid (FFA) content of a feedstock when present in excess of $1 \mathrm{wt} \%$ is a two step process, where acidic pretreatment of the feedstock is first done to lower its FFA content followed by homogenous base catalyst based transesterification to produce biodiesel [20-23]. KCDL feedstock had an exceptionally high acid value of 


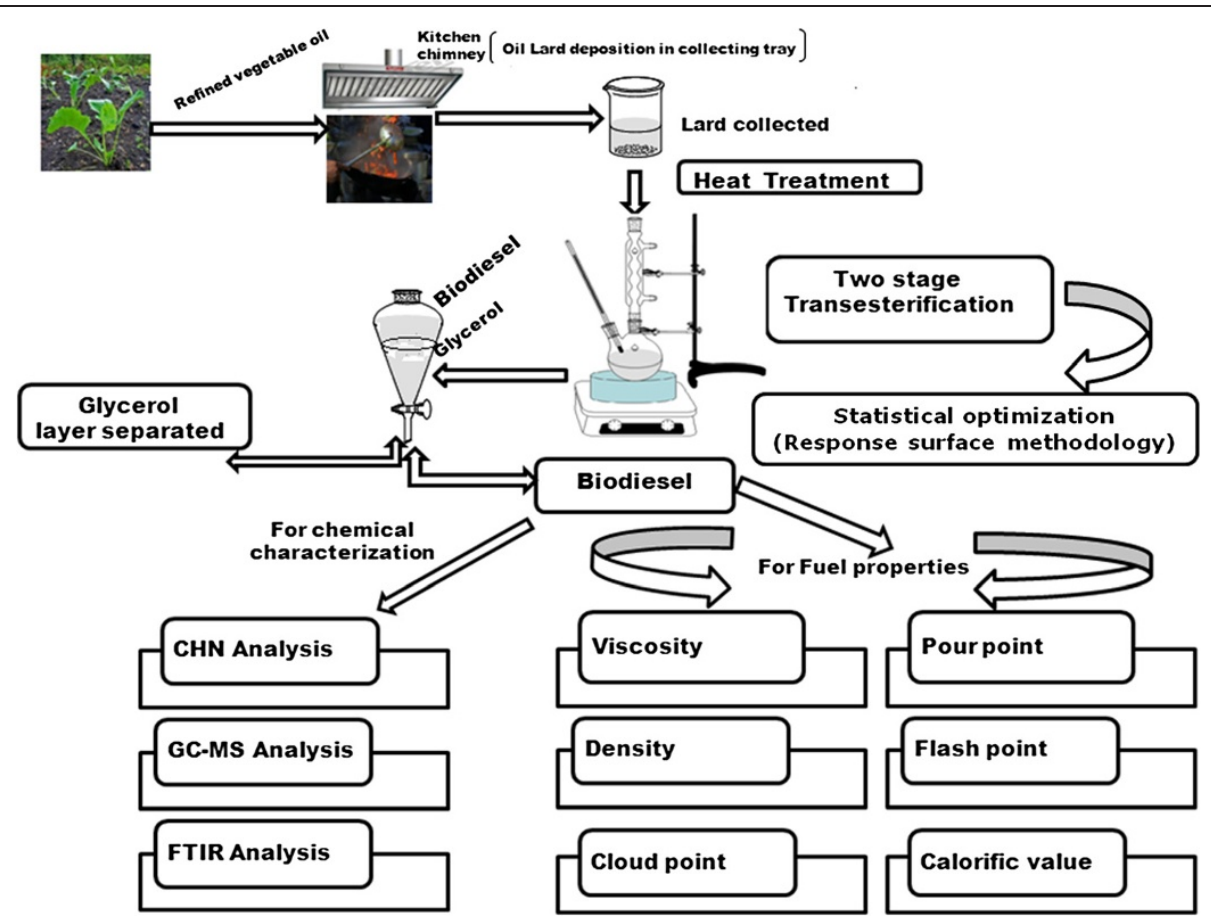

Figure 1 Graphical abstract from feedstock collection to biodiesel production and subsequent characterization.

$28 \mathrm{mg} \mathrm{KOH} / \mathrm{gm}$ and henceforth biodiesel was produced by a two stage transesterification process. The first stage esterification (acidic) was catalyzed by conc. $\mathrm{H}_{2} \mathrm{SO}_{4}$ whereas the second stage (basic) by $\mathrm{NaOH}$.

The elemental content of carbon, hydrogen, nitrogen and oxygen in the biodiesel sample were 59.98, 9.51, 0.69 and 29.82 respectively. The lower content of nitrogen in the biodiesel sample is important especially with regard to environmental protection. The major difference between biofuels and petroleum feedstocks is oxygen content. The oxygen content in biofuels ranges from 10 to $45 \%$ while petroleum has essentially none, making the chemical properties of biofuels quiet different from those of petrofuels [24]. The Gross calorific value (GCV) and Net calorific value (NCV) for KCDL biodiesel was $36.5 \mathrm{MJ} / \mathrm{Kg}$ and $34.40 \mathrm{MJ} / \mathrm{Kg}$ respectively, which is slightly lower than that reported by Demirbas for other biodiesels (39 to $41 \mathrm{MJ} / \mathrm{Kg}$ ) [24]. The GCV for KCDL biodiesel was less than that reported by Sharon et. al, for methyl esters (biodiesel) derived from veg fried oil and non-veg fried oil viz., $42.59 \mathrm{MJ} / \mathrm{Kg}$ and $42.38 \mathrm{MJ} / \mathrm{kg}$ respectively [25].

The present investigation included optimization of biodiesel yield by RSM. Biodiesel yield (wt \%) relative to the weight of KCDL was estimated. The RSM experiment was not extended for the pre-treatment step (acid catalyzed esterification). The statistical optimization employed using Box-Behnken [26] design showing the level of four independent variables includes Methanol $\left(X_{1}\right), \mathrm{NaOH}\left(X_{2}\right)$, Temperature $\left(X_{3}\right)$ and Time $\left(X_{4}\right)$ were further investigated at three different levels as listed in Table 1.). Table 1 showed the design matrix of the variables with the experimental results of the biodiesel yield. The experimental results were displayed in the form of threedimensional response surface plots and contour plots.

Figure 2 described the contour plots which explore the relationship between the variables used in the present investigation i.e. methanol, $\mathrm{NaOH}$, temp, and time for biodiesel yield. The plot displays the three dimensional relationship in the form of a two dimensional plot. In Figure 2 contours levels viz. methanol, $\mathrm{NaOH}$, temperature and time which influence the biodiesel yield is represented.

The salient findings of RSM methodology were

i) gradual increase in biodiesel yield with high level of $\mathrm{NaOH}$ and temperature (Figure 3A).

ii) increase in biodiesel yield with increase in the level of methanol and time (Figure 3B).

iii) increase in yield with increment in the level of $\mathrm{NaOH}$ and decrease in yield with increment in time (Figure 3C).

iv) decrease in biodiesel yield with increase in the level of methanol and $\mathrm{NaOH}$ (Figure 3D). 
Table 1 Box-Behnken experimental design, representing the response of biodiesel yield as influenced by methanol, $\mathrm{NaOH}$, temperature and time

\begin{tabular}{|c|c|c|c|c|c|c|}
\hline Run order & Methanol & $\mathrm{NaOH}$ & Temperature & Time & Yield & Predicted yield \\
\hline 1 & 0 & -1 & 0 & 1 & 80 & 81.179 \\
\hline 2 & 0 & 1 & 0 & -1 & 75 & 75.647 \\
\hline 3 & 0 & 0 & 0 & 0 & 83 & 84.202 \\
\hline 4 & 0 & 0 & -1 & -1 & 84 & 83.904 \\
\hline 5 & 1 & 1 & 0 & 0 & 81 & 81.772 \\
\hline 6 & 0 & 0 & -1 & 1 & 85 & 86.571 \\
\hline 7 & 1 & 0 & 0 & -1 & 80 & 78.821 \\
\hline 8 & -1 & 1 & 0 & 0 & 75 & 73.396 \\
\hline 9 & 0 & 1 & 0 & 1 & 79 & 79.314 \\
\hline 10 & -1 & 0 & -1 & 0 & 84 & 85.648 \\
\hline 11 & 1 & -1 & 0 & 0 & 84 & 81.733 \\
\hline 12 & 0 & 0 & 0 & 0 & 82 & 84.202 \\
\hline 13 & 0 & -1 & 1 & 0 & 95 & 94.083 \\
\hline 14 & -1 & 0 & 1 & 0 & 87 & 87.424 \\
\hline 15 & 0 & 1 & -1 & 0 & 84 & 83.355 \\
\hline 16 & 0 & -1 & -1 & 0 & 95 & 89.316 \\
\hline 17 & -1 & 0 & 0 & -1 & 89 & 89.349 \\
\hline 18 & 1 & 0 & -1 & 0 & 78 & 81.206 \\
\hline 19 & 0 & 1 & 1 & 0 & 80 & 79.313 \\
\hline 20 & 0 & 0 & 0 & 0 & 84 & 84.202 \\
\hline 21 & 1 & 0 & 1 & 0 & 82 & 83.982 \\
\hline 22 & 1 & 0 & 0 & 1 & 85 & 82.487 \\
\hline 23 & 0 & 0 & 1 & 1 & 79 & 79.433 \\
\hline 24 & 0 & -1 & 0 & -1 & 93 & 94.513 \\
\hline 25 & -1 & -1 & 0 & 0 & 94 & 94.166 \\
\hline 26 & -1 & 0 & 0 & 1 & 77 & 76.016 \\
\hline 27 & 0 & 0 & 1 & -1 & 93 & 91.766 \\
\hline
\end{tabular}
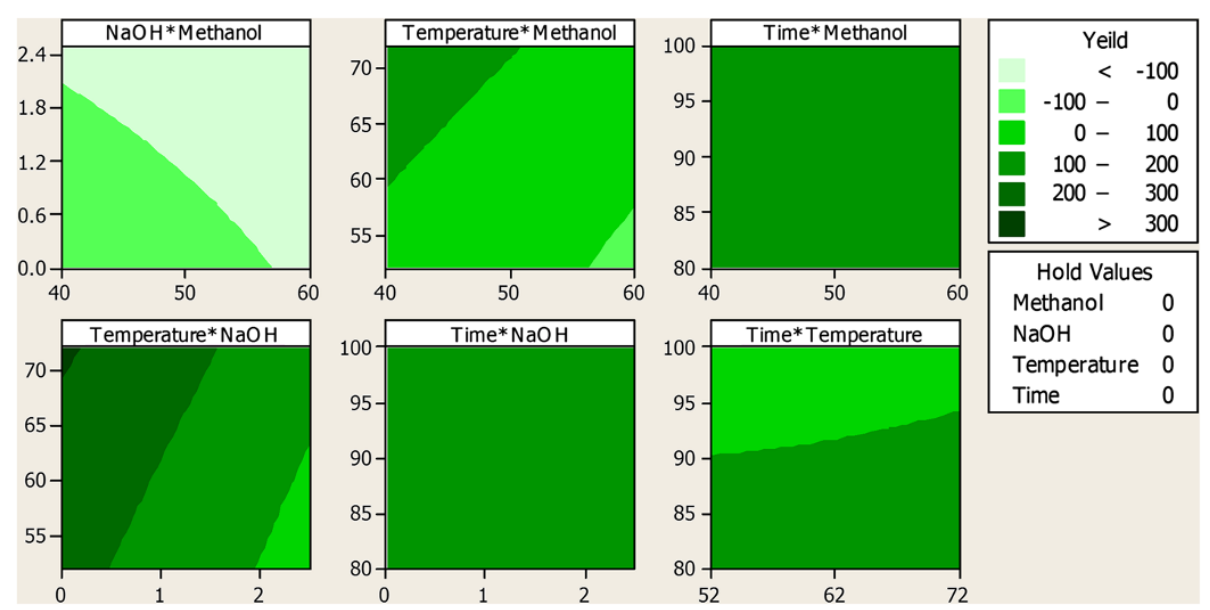

Figure 2 Contour plots of biodiesel yield as influenced by methanol, $\mathrm{NaOH}$, temperature and time. The darker green contour region represents higher biodiesel yield ( $>300)$ while the lighter green colour represents lower biodiesel yield $(<-100)$. 
For predicting the optimal point, a second order polynomial function was fitted to the experimental results of biodiesel yeild:

$$
\begin{aligned}
\text { Y activity }= & 113.430+3.053 X_{1}+55.130 X_{2}+0.934 X_{3} \\
& +1.694 X_{4}+0.520 X_{1} X_{2}+0.007 X_{1} X_{3} \\
& +0.043 X_{1} X_{4}+0.220 X_{2} X_{3}+0.425 X_{2} X_{4} \\
& +0.038 X_{3} X_{4}
\end{aligned}
$$

Where, $X_{1}, X_{2}, X_{3}$ and $X_{4}$ are the Methanol, $\mathrm{NaOH}$, temperature and time respectively.

The regression model (eq. 1) fits the experimental data well with a high $R^{2}$ (coefficient of determination) value of $90.81 \%$. The value of $\mathrm{R}^{2}$ thus obtained suggests a high degree of correlation between the experimental and the predicted values. The closer the value of $R^{2}$ to 1.00 , the stronger is the correlation between the measured and the predicted values. In the present investigation the calculated coefficient of determination value indicates that the model could explain $90.81 \%$ of the variability in the response.

To find out the optimum condition and to confirm the validity and accuracy of the model, an experiment was carried out under basal and predicted optimal conditions where biodiesel yield was monitored compared to the calculated data from the model. The estimated biodiesel yield was $82 \%$ compared to $80 \%$ of the predicted value from the polynomial model. Thus, it points out the accuracy of the model with more than $97.56 \%$ which is an evidence for the model validation. However, this variance of biodiesel yield might be because of slight variation in the experimental conditions. In short, the statistical optimization was applied to find out the optimal biodiesel yield and found to be an effective statistical technique for higher biodiesel yield.

The FTIR spectra of the feedstock and biodiesel, shown in Figure 4, are quiet similar since both have almost the same chemical groups. The IR spectra of KCDL biodiesel shows a $\mathrm{C}=\mathrm{O}$ stretching band of methyl esters at $1748 \mathrm{~cm}^{-1}$ and $\mathrm{C}-\mathrm{O}$ bands at 1130 and 1196 $\mathrm{cm}^{-1}$ [27]. The aliphatic hydrogen at $2928 \mathrm{~cm}^{-1}$ and 2856 $\mathrm{cm}^{-1}$ are indicative that the main components of the biodiesel sample are long carbon chains [28]. C-H deformations between $1500-1300 \mathrm{~cm}^{-1}$ further verify the presence of long carbon chains [29].

The identification of FAME's (shown in Table 2) by GCMS analysis was performed through comparison of their mass spectra with those in NIST library. The saturated and unsaturated FAME in the biodiesel sample were 41.86 and $58.14 \%$ respectively. A high degree of saturation is likely to make the fuel more stable. The average molecular weight of the KCDL methyl esters was 276.34 .
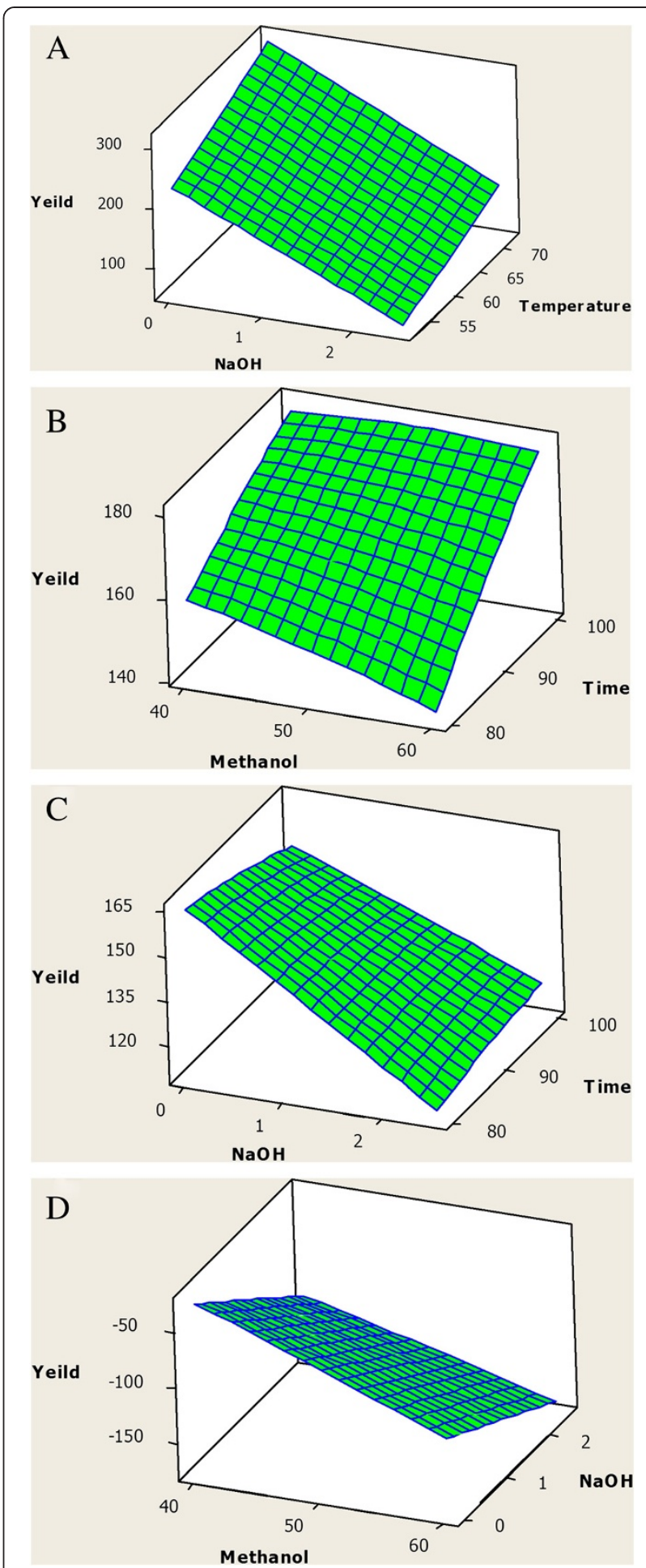

Figure 3 Response surface showing the surface plot of (3A) Yeild vs Temperature, $\mathrm{NaOH}$ (3B) Yeild vs Time, Methanol (3C) Yeild vs Time, $\mathrm{NaOH}$ and (3D) Yeild vs $\mathrm{NaOH}$, Methanol.

There exists variability in the chemical composition of different biodiesel feedstocks, and henceforth variations in the fuel properties of biodiesel produced from different 


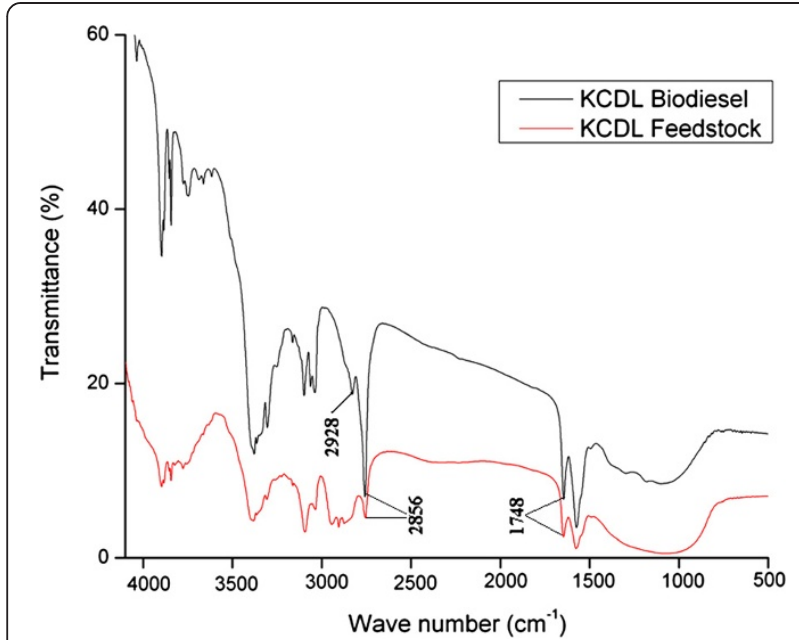

Figure 4 FTIR spectra of KCDL feedstock and KCDL biodiesel.

feedstocks is imperative. The fuel characterization of KCDL based biodiesel has been presented in Table 3. The high viscosity $\left(8.7 \mathrm{~mm}^{2} / \mathrm{s}\right)$ of $\mathrm{KCDL}$ based biodiesel in contrast to others viz., waste cooking oil $\left(4.89 @ 40^{\circ} \mathrm{C}, \mathrm{mm}^{2} / \mathrm{s}\right)$ [30], methyl esters of veg fried oil $\left(5.11 @ 40^{\circ} \mathrm{C}, \mathrm{mm}^{2} / \mathrm{s}\right)$ and methyl esters of non-veg fried oil $\left(5.81 @ 40^{\circ} \mathrm{C}, \mathrm{mm}^{2} / \mathrm{s}\right)[25]$ is the major bottleneck for practical usability of the fuel in diesel engine. However, use of biosurfactants (being environmentally benign in nature in contrast to chemical surfactants) for reducing the viscosity of the sample fuel is in progress and will be reported in subsequent publications. Also, for our work it is also very important to realize the blending of biodiesel with petrodiesel for determining the optimum blending composition and subsequent blend characterization.

\section{Conclusion}

Global trends pertaining to energy crisis, energy security and environmental deterioration will significantly contribute towards the investigation of newer bio-based feedstocks for biofuel production. Several studies have been carried out regarding the production of biodiesel from edible and non-edible sources describing the feasibility of making biodiesel from these feedstocks. The

\section{Table 2 FAME's identifiable by GC-MS analysis}

\begin{tabular}{cccc}
\hline SN & Fatty acid methyl ester (FAME) & $\begin{array}{c}\text { Molecular } \\
\text { formula }\end{array}$ & $\begin{array}{c}\mathbf{W t} \\
\mathbf{( \% )}\end{array}$ \\
\hline 1 & Nonanedioic acid, dimethyl ester & $\mathrm{C}_{11} \mathrm{H}_{20} \mathrm{O}_{4}$ & 5.68 \\
2 & Tetradecanoic acid, 10,13-dimethyl-, & $\mathrm{C}_{17} \mathrm{H}_{34} \mathrm{O}_{2}$ & 34.95 \\
& methyl ester & & \\
3 & 9-octadecenoic acid, methyl ester, (E)- & $\mathrm{C}_{19} \mathrm{H}_{36} \mathrm{O}_{2}$ & 39.92 \\
4 & 9-hexadecenoic acid, methyl ester, (Z)- & $\mathrm{C}_{17} \mathrm{H}_{32} \mathrm{O}_{2}$ & 18.82 \\
5 & Heptacosanoic acid, 25-methyl, & $\mathrm{C}_{29} \mathrm{H}_{58} \mathrm{O}_{2}$ & 1.21 \\
& methyl ester & & \\
\hline
\end{tabular}

Note: Saturated $=41.86 \%$ and unsaturated $=58.14 \%$. present investigation was carried out to evaluate KCDL as a potential feedstock for biodiesel production. The study clearly suggests that the production of biodiesel from KCDL feedstock is feasible. Moreover, the application of RSM is quite helpful in design of experiments for optimal biodiesel production and allied approaches. The fuel under investigation may also be blended with petrodiesel for determining the fuel characteristics of the blends and thereby determining the optimum blending composition (a part of planned future research activity). In addition, the study also requires greater research capacities (viscosity reduction, oxidative stability etc.) to enable a better comprehensive understanding of biodiesel production from KCDL. On a global scale tons of raw feedstock (deposited lard in kitchen chimneys) may be collected annually and henceforth true techno-economic evaluation of the process is necessary in a pilot scale. Conclusively, research endeavors in newer feedstocks for biofuel production will serve as an incremental step in further efforts related to bio-energy.

\section{Experimental}

\section{Determination of acid value}

The acid value of the sample was determined by titrating it against $\mathrm{KOH}$ using phenolphthalein as an indicator. The calculations were done using the following formula [31]

$$
\begin{aligned}
\text { Acid value }(\mathrm{mg} \mathrm{KOH} / \mathrm{gm})= & \text { Titre value } \\
\times & \text { Normality of } \mathrm{KOH} \\
\times & 56.1 / \text { Weight of the } \\
& \text { sample }(\mathrm{gm})
\end{aligned}
$$

Where, the factor 56.1 is taken from Equivalent weight of $\mathrm{KOH}$ since $1 \mathrm{ml} 1 \mathrm{~N} \mathrm{KOH}$ contains $56.1 \mathrm{mg}$ weight of $\mathrm{KOH}$.

\section{Transesterification}

A two stage transesterification process was used for production of biodiesel from KCDL. In the first stage, concentrated $\mathrm{H}_{2} \mathrm{SO}_{4}$ (97\% purity) was used as an acid catalyst to convert high FFAs to esters and in the second stage $\mathrm{NaOH}$ was used as an alkali catalyst to convert triglycerides to biodiesel. The standard biodiesel reaction mixture consisted of KCDL, methanol and appropriate concentration of catalysts (acid and basic).

\section{Heat treatment of feedstock}

Prior to acidic esterification the KCDL feedstock was heated at $120^{\circ} \mathrm{C}$ for $30 \mathrm{~min}$. This step is required to melt all the solid fat present in the feedstock.

\section{Two stage transesterification and statistical optimization} The sample from the previous step was taken and allowed to cool to a temperature of $50^{\circ} \mathrm{C}$ and required 
Table 3 Biodiesel properties

\begin{tabular}{lll}
\hline Properties & $\begin{array}{l}\text { KCDL } \\
\text { Biodiesel }\end{array}$ & Standard test method used \\
\hline $\begin{array}{l}\text { Density }\left(40^{\circ} \mathrm{C}, \mathrm{g} / \mathrm{cm}^{3}\right) \\
\text { Viscosity }\left(\mathrm{mm}^{2} / \mathrm{s}, \mathrm{CSt} \text { at }\right.\end{array}$ & 0.9 & ASTM D 5002 \\
$\left.40^{\circ} \mathrm{C}\right)$ & ASTM D 445 \\
$\begin{array}{l}\text { Cloud point }\left({ }^{\circ} \mathrm{C}\right) \\
\text { Pour point }\left({ }^{\circ} \mathrm{C}\right)\end{array}$ & 8 & ASTM D 2500 \\
$\begin{array}{l}\text { Gross calorific value }(\mathrm{MJ} / \\
\mathrm{kg})\end{array}$ & 36.5 & ASTM D 97 \\
$\begin{array}{l}\text { Net calorific value }(\mathrm{MJ} / \\
\mathrm{kg})\end{array}$ & 34.40 & Adiabatic Bomb Calorimeter \\
Flash point $\left({ }^{\circ} \mathrm{C}\right)$ & 123 & Equation for calculation of \\
Ash content $(\mathrm{Wt} \%)$ & 0.05 & ASTM D 93 \\
\hline
\end{tabular}

Note: Determination of cetane number was not a part of this study.

amount of methanol ( $60 \%$ by vol, $99 \%$ purity) was added. Following this, $\mathrm{H}_{2} \mathrm{SO}_{4}$ (3\% v/v, 97\% purity) was added to the mixture and the reaction was commenced at $50^{\circ} \mathrm{C}$ with $600 \mathrm{rpm}$ for $60 \mathrm{~min}$. Once completed the reaction mixture was placed in a separating funnel and left to stay overnight. The upper layer being a mixture of unreacted triglycerides, unreacted methanol and esters was separated from the lower layer. This layer was washed thrice with warm water $\left(\sim 60^{\circ} \mathrm{C}\right)$ to remove the unreacted catalyst and methanol. Finally the product (esterified) was heated at $115^{\circ} \mathrm{C}$ for $20 \mathrm{~min}$ to ensure moisture removal.

The second phase of the two stage transesterification process (alkali catalyzation) was optimized using response surface methodology (RSM). RSM explores the relationships between the explanatory variables with the response variables. Its main idea is to obtain an optimal response using a sequence of designed experiments $[32,33]$. In the present investigation, Box-Behnken design [27] experiment for RSM was employed for four independent variables viz. Methanol $\left(X_{1}\right), \mathrm{NaOH}\left(X_{2}\right)$, Temperature $\left(X_{3}\right)$ and Time $\left(X_{4}\right)$ for the optimal biodiesel yield during the second stage transesterification step. The ranges of the four variables studied is shown in Table 4 and the factors of highest confidence levels were represented in three levels, coded -1 for low, 0 for middle and +1 for high.

The actual design matrix of 27 trials of experiments is given in Table 1 . The actual experiments were

Table 4 The levels of variables chosen for the BoxBehnken optimization experiment for biodiesel yield

\begin{tabular}{lllll}
\hline Variables & Variable code & $\mathbf{- 1}$ & $\mathbf{0}$ & $\mathbf{+ 1}$ \\
\hline Methanol & $X_{1}$ & 40 & 50 & 60 \\
$\mathrm{NaOH}$ & $X_{2}$ & .5 & 1.5 & 2.5 \\
Temperature & $X_{3}$ & 52 & 62 & 72 \\
Time & $X_{4}$ & 80 & 90 & 100 \\
\hline
\end{tabular}

performed and the values are presented as yield in Table 1 . The behaviour of the system can be explained by the quadratic equation

$$
\begin{aligned}
Y= & \beta_{0}+\beta_{1} X_{1}+\beta_{2} X_{2}+\beta_{3} X_{3}+\beta_{4} X_{4}++\beta_{12} X_{1} X_{2} \\
& +\beta_{13} X_{1} X_{3}+\beta_{14} X_{1} X_{4}+\beta_{23} X_{2} X_{3}+\beta_{24} X_{2} X_{4} \\
& +\beta_{34} X_{3} X_{4}
\end{aligned}
$$

where, $\mathrm{Y}$ is the predicted response, $\beta_{0}$ model constant; $X_{1}, X_{2}, X_{3}$ and $X_{4}$ independent variables; $\beta_{1}, \beta_{2}, \beta_{3}$ and $\beta_{4}$ are linear coefficients; $\beta_{12}, \beta_{13}, \beta_{14}$ and $\beta_{23}$ are cross product coefficients and $\beta_{11}, \beta_{22}$ and $\beta_{33}$ are the quadratic coefficients.

Further, the experimental data obtained were interpreted using Minitab 15 statistical software [34] to estimate the response of dependent variable. The quality of fitness of the polynomial model equation was expressed by the coefficient of determination $\left(R^{2}\right)$.

In the present optimization the optimized values were 40.08 for methanol $\left(X_{1}\right), 1.86$ for $\mathrm{NaOH}\left(X_{2}\right), 52$ for temperature $\left(X_{3}\right)$ and 100 for time $\left(X_{4}\right)$ from the response surface optimizer.

AS per the optimization response, $1.86 \% \mathrm{NaOH}$ (by wt) was dissolved in 40\% (by vol) methanol (99\% purity) to prepare the alkali catalyst-methanol mixture. This mixture was prepared freshly to maintain catalytic activity and prevent moisture absorbance. Following this the alkali catalyst-methanol mixture was added to the esterified product and alkali transesterification was commenced at $52^{\circ} \mathrm{C}$ with $600 \mathrm{rpm}$ for $100 \mathrm{~min}$. The reaction mixture was then placed in a separating funnel and left to stay overnight. Two distinct layers were formed, the upper layer (biodiesel) and the lower layer (glycerol). The two layers were gravity separated with glycerol simply drained off from the bottom of the separating funnel. The separated biodiesel layer was subjected to the same washing and heat treatment as of the acidic esterification stage. Biodiesel yield (wt \%) relative to the weight of KCDL was estimated.

\section{FTIR analysis}

The IR spectrum of the samples (KCDL feedstock and biodiesel) was recorded in a (Perkin Elmer, Spectrum100) spectrometer at room temperature $\left(26 \pm 2^{\circ} \mathrm{C}\right)$ in the mid IR range $4000-400 \mathrm{~cm}^{-1}$.

\section{Determination of Gross calorific value (GCV)}

The Gross calorific value of the biodiesel was determined using an automatic adiabatic bomb calorimeter (Changsha Kaiyuan Instruments Co., 5E-1AC/ML). The sample ( $1 \mathrm{ml}$ biodiesel) was oxidized by combustion in an adiabatic bomb containing 3.1 Mpsi oxygen under pressure. The assays were carried out in triplicates and the mean values are reported [35]. 


\section{Determination of Net calorific value (NCV)}

The equation for calculation of NCV is as follows [36]

$$
\begin{aligned}
\mathrm{NCV}= & \mathrm{GCV} \times\left(1-\frac{w}{100}\right)-2.444 \times\left(\frac{w}{100}\right)-2.444 \\
& \times\left(\frac{H}{100}\right) \times 8.936 \times\left(1-\frac{w}{100}\right) ;\left[\frac{M J}{K g}, w . b .\right]
\end{aligned}
$$

Where 2.444=Enthalpy difference between gaseous and liquid water at $25^{\circ} \mathrm{C}$.

$8.936=\frac{M_{H_{2} O}}{M_{H_{2}}} ;$ i.e. the molecular mass relation between $\mathrm{H}_{2} \mathrm{O}$ and $\mathrm{H}_{2}$
Where,

$\mathrm{NCV}=$ Net calorific value

$\mathrm{GCV}=$ Gross calorific value

$\mathrm{h}=$ Concentration of hydrogen in weight $\%$

$\mathrm{w}=$ Moisture content of the fuel in weight $\%$

\section{Determination of fatty acid profile}

The fatty acid methyl ester (FAME) profile (shown in Figure 5) was analyzed by a Perkin Elmer Clarus 600 gas chromatograph (GC) coupled with a Perkin Elmer Clarus 600C mass spectrometer (MS) equipped with Elite $5 \mathrm{MS}$ capillary column $(30 \mathrm{~m} \times 0.25 \mathrm{~mm} \times 0.25 \mu \mathrm{m})$.

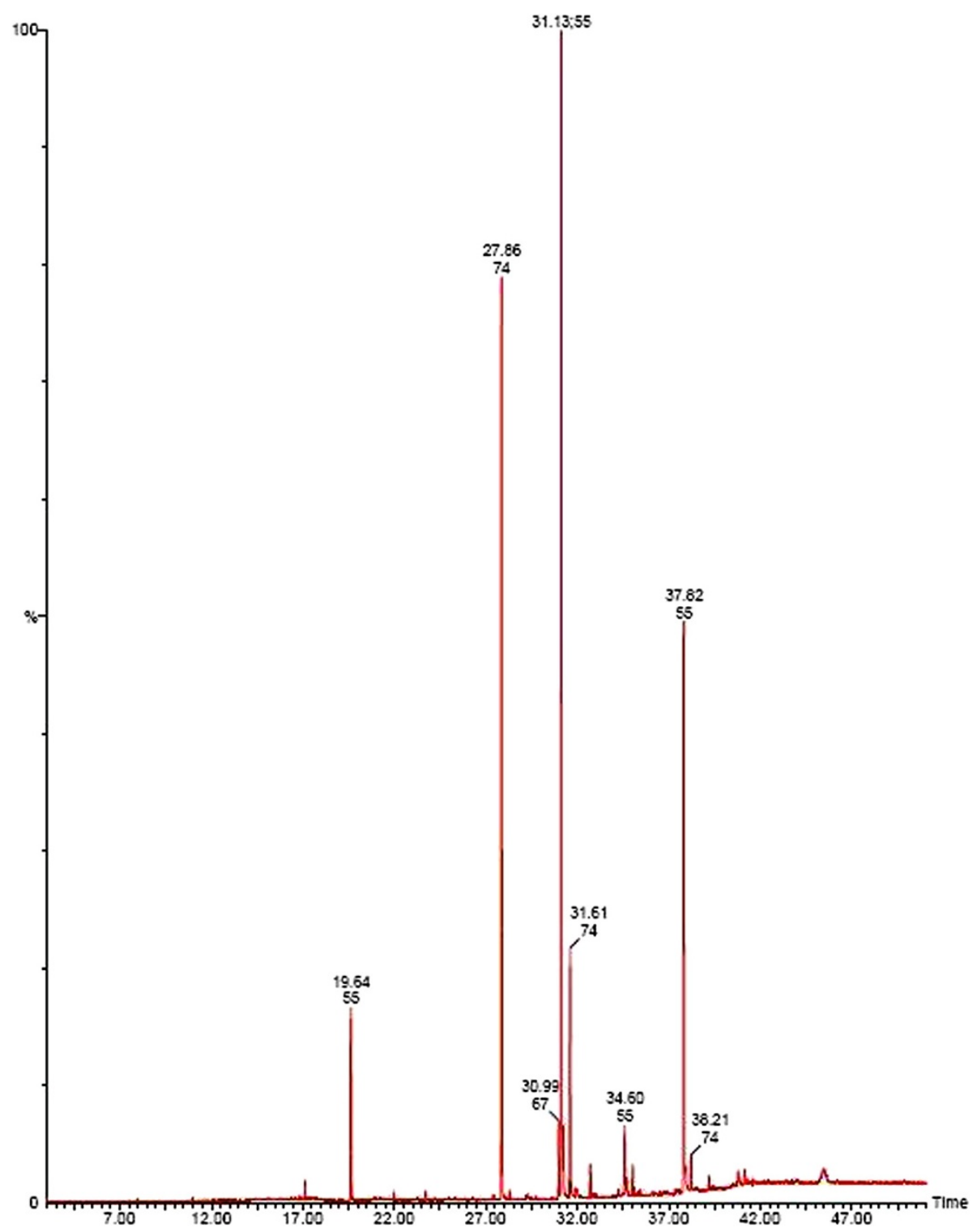

Figure 5 GCMS profile of KCDL Biodiesel. 
The oven temperature was programmed from $85^{\circ} \mathrm{C}$ (5 min) to $265^{\circ} \mathrm{C}$ at a rate of $5^{\circ} \mathrm{C} / \mathrm{min}$ and finally held at $265^{\circ} \mathrm{C}$ for $10 \mathrm{~min}$. Helium was used as the carrier gas with a flow rate of $1 \mathrm{ml} / \mathrm{min}$. The MS was operated in electron ionization mode at $70 \mathrm{eV}$. The interface temperature was $265^{\circ} \mathrm{C}$ and the mass range was $15-650$ $\mathrm{m} / \mathrm{z}$. The identification of fatty acids was performed, comparing the obtained mass spectra with NIST library.

\section{Analysis of KCDL based biodiesel}

The properties of biodiesel viz. density, viscosity, cloud point, pour point, flash point and calorific value were determined using standard methods and the results are presented in Table 3. The carbon, nitrogen and hydrogen content of the biodiesel sample were determined in a Perkin Elmer, 2400 Series-II analyzer. The percentage of oxygen was calculated by difference.

\section{Abbreviations \\ KCDL: Kitchen chimney dump lard; RSM: Response surface methodology; CHN analyzer: Carbon hydrogen and nitrogen analyzer; GC-MS: Gas chromatography-mass spectra; FTIR: Fourier transform infra red spectroscopy; FFA: Free fatty acids; GCV: Gross calorific value; NCV: Net calorific value; IR: Infra red; FAME: Fatty acid methyl ester.}

\section{Competing interests}

The authors declare that they have no competing interests.

\section{Authors' contributions}

MMP, TB carried out FTIR analysis, GCMS and fuel characterization. SPS carried out the statistical optimization. ND carried out the CHN analysis. MMP, SPS, PP and BKK conceived of the study, and participated in its design and coordination and helped to draft the manuscript. All authors read and approved the final manuscript.

\section{Acknowledgement}

MMP thanks Dept. of Science \&Technology, New Delhi for providing research grant in the form of DST-INSPIRE fellowship. SPS thanks Dr. T. Madhan Mohan, Adviser, Dept. of Biotechnology, New Delhi, India for promoting Bioinformatics in North-East India. MMP \& SPS thank ViceChancellor, Tezpur University, Assam for encouragement.

\section{Author details}

'Department of Molecular Biology \& Biotechnology, School of Science \& Technology, Tezpur University, Assam Napaam-784028, India. ${ }^{2}$ Department of Energy, School of Engineering, Tezpur University, Assam Napaam-784028, India. ${ }^{3}$ Department of Chemical Science, School of Science \& Technology, Tezpur University, Assam Napaam-784028, India.

Received: 6 February 2013 Accepted: 22 July 2013

Published: 6 August 2013

\section{References}

1. Wackett LP: Biomass to fuels via microbial transformations. Curr Opin Chem Biol 2008, 12:187-93.

2. Khandekar ML, Murty TS, Chittibabu P: The global warming debate: a review of the state of science. Pure App/ Geophys 2005, 162:1557-86.

3. Hall DO: Biomass energy in industrialised countries - a view of the future. Forest Ecol Manag 1997, 91:17-45.

4. Hall DO, Scrase J: Will biomass energy be the environmentally friendly fuel of the future? Biomass and Bioenergy 1998, 15:357-67.

5. Hall DO, Scrase Jl, Rosillo-Calle F: Biomass energy: the global context now and in the future. Aspect App/ Biol 1997, 49:1-10.

6. European Commission: Energy for the future: renewable sources of energy, White paper for a community strategy and action plan. 1997. COM/1997/
599 final 1-55 http://europa.eu/documents/comm/white_papers/pdf/ com97_599_en.pdf Accessed 18 ${ }^{\text {th }}$ Jan 2013.

7. Kartha $\bar{S}$, Larson ED: Bioenergy primer: Modernized biomass energy for sustainable development. 1 United Nations Plaza, New York, NY 10017, USA United Nations Development Programme, United Nations Publications; 2000.

8. Ravindranath $\mathrm{NH}$, Hall DO: Biomass, energy, and environment: a developing country perspective from India. Oxford: UK: Oxford University Press; 1995

9. Reddy AKN, Williams RH, Johansson TB: Energy after Rio; Prospects and challenges. New York, NY, USA: United Nations Development Programme; 1997

10. Johansson TB, Kelly H, Reddy AKN, Williams RH: Renewable energy: sources for fuels and electricity. Washington, DC: Island Press, UNDP/WEC; 1993.

11. World energy assessment: energy and the challenges of sustainability: United Nations development Programme. United Nations Department of Economic and Social Affairs. New York, USA: World Energy Council; 2001.

12. Berndes $G$, Hoogwijk M, van den Broek: The contribution of biomass in the future global energy supply: a review of 17 studies. Biomass Bioenergy 2003, 25:1-28

13. Mckendry P: Energy production from biomass (part 1): overview of biomass. Bioresour Technol 2002, 83:37-46.

14. Kondamudi N, Mohapatra SK, Misra M: Spent coffee grounds as a versatile source of green energy. J Agric Food Chem 2008, 56:11757-11760.

15. Tao L, Aden A: The economics of current and future biofuels. In Vitro Cell Dev Biol Plant 2009, 45:199-217

16. Murray KE, Healy FG, McCord RS, Shields JA: Biomass production and nutrient uptake by Neochloris oleoabundans in an open trough system. Appl Microbiol Biotechnol 2011, 90:89-95.

17. Bryan RM: Biodiesel production, properties, and feedstocks. In Vitro Cell Dev Biol_Plant 2009, 45:229-266.

18. Vasudevan PT, Briggs M: Biodiesel production-current state of the art and challenges. J Ind Microbiol Biotechnol 2008, 35:421-30.

19. Canakci M, Van Gerpen J: Biodiesel production via acid catalysis. Trans ASAE 1999, 42:1203-10.

20. Freedman B, Pryde EH, Mounts TL: Variables affecting the yields of fatty esters from transesterified vegetable oils. J Am Oil Chem Soc 1994, 61:1638-1643.

21. Mbaraka IK, Radu DR, Lin VSY, Shanks BH: Organosulfonic acidfunctionalized mesoporous silicas for the esterification of fatty acid. J Catal 2003, 219:329-336.

22. Zhang Y, Dube MA, McLean DD, Kates M: Biodiesel production from waste cooking oil via two-step catalyzed process. Energ Convers Manage 2003, 48:184-188.

23. Wang PS, Tat ME, Van GJ: The production of fatty acid isopropyl esters and their use as a diesel engine fuel. J Am Oil Chem Soc 2005, 82:845-849.

24. Demirbas A: Biodiesel: A Realistic Fuel Alternative for Diesel Engines. SpringerVerlag London Limited; 2008. doi:10.1007/978-1-84628-995-8.

25. Sharon H, Jayaprakash R, Karthigai MS, Soban DR, Sundaresan A, Karuppasamy K: Biodiesel production and prediction of engine performance using SIMULINK model of trained neural network. Fuel 2012, 99:197-203.

26. Box GEP, Behnken DW: Some new three level designs for the study of quantitative variables. Technometrics 1960, 2:455-475.

27. Tariq M, Ali S, Ahmad F, Ahmad M, Zafar M, Khalid N, Khan MA: Identification, FT- IR, NMR ( ${ }^{1} \mathrm{H}$ and ${ }^{13} \mathrm{C}$ ) and GC/MS studies of fatty acid methyl esters in biodiesel from rocket seed oil. Fuel Process Tech 2011, 92:336-41.

28. Xiaoxiang J, Ellis N, Zhaoping Z: Fuel properties of bio-oil/bio-diesel mixture characterized by TG, FTIR and ${ }^{1} \mathrm{H}$ NMR. Korean J Chem Eng 2011 28:133-137.

29. Cheila GM, Bruno CS, Michelle GM: Characterization by TG/DTG/DSC and FTIR of frying and fish oil residues to obtain biodiesel. J Therm Anal Calorim 2011, 106:811-817.

30. Anh NP, Tan MP: Biodiesel production from waste cooking oils. Fuel 2008, 87:3490-3496

31. Sadashivam S, Manickam A: Biochemical methods. 2nd edition. New Delhi, India: New Age International (P) Limited, Publishers; 1996.

32. Box GEP, Wilson KB: On the Experimental Attainment of Optimum Conditions (with discussion). J Roy Stat Soc Stat SoC 1951, 13:1-45. 
33. Box GEP, Draper N: Response Surfaces, Mixtures, and Ridge Analyses, [of Empirical Model-Building and Response Surfaces, 1987]. 2nd edition. New York, USA: John Wiley \& Sons; 2007.

34. Minitab 15 Statistical Software: Computer software. PA, USA: Minitab, Inc. 2010. www.minitab.com.

35. Phukan MM, Chutia RS, Konwar BK, Kataki R: Microalgae Chlorella as a potential bio- energy feedstock. Appl Energy 2011, 88:3307-3312.

36. Evald A, Koppejan J, Livingston W, Nussbaumer T, Obernberger I, Skreiberg $\mathrm{Q}$ : Biomass fuel properties and basic principles of biomass combustion. In Handbook of biomass combustion and co- 441 firing. Edited by Loo 440 SV, Koppejan J. London: Earthscan; 2008:7-53.

doi:10.1186/2043-7129-1-12

Cite this article as: Phukan et al:: Production and statistical optimization of biodiesel from kitchen chimney dump lard. Sustainable Chemical

Processes 2013 1:12.

\section{Publish with ChemistryCentral and every scientist can read your work free of charge \\ "Open access provides opportunities to our colleagues in other parts of the globe, by allowing anyone to view the content free of charge." \\ W. Jeffery Hurst, The Hershey Company. \\ - available free of charge to the entire scientific community \\ - peer reviewed and published immediately upon acceptance \\ - cited in PubMed and archived on PubMed Central \\ - yours - you keep the copyright \\ Submit your manuscript here: \\ http://www.chemistrycentral.com/manuscript/<smiles>c1ccccc1</smiles> 